DOI: 10.46340/eppd.2020.7.6.28

Oleh Stets, PhD in Law

ORCID ID: https://orcid.org/0000-0003-4211-2687

Kryvyi Rih Faculty of the National University "Odesa Law Academy», Ukraine

\title{
SUBMISSION OF THE DECLARATION \\ OF PERSONS AUTHORIZED TO PERFORM \\ THE FUNCTIONS OF THE STATE OR LOCAL SELF-GOVERNMENT AS A DUTY OF A CIVIL SERVANT
}

\author{
Олег Стець, к. ю. н. \\ Криворізький факультет Національного університету "Одеська юридична \\ академія», Україна \\ ПОДАННЯ ДЕКЛАРАЦІЇ ОСІБ, УПОВНОВАЖЕНИХ \\ НА ВИКОНАННЯ ФУНКЦЙ ДЕРЖАВИ \\ АБО МІСЦЕВОГО САМОВРЯДУВАННЯ \\ ЯК ОБОВ'ЯЗОК ДЕРЖАВНОГО СЛУЖБОВЦЯ
}

\begin{abstract}
The article is devoted to the study of the essential features of the duty of the civil servant to submit a declaration of persons authorized to perform the functions of the state or local self-government. It is established that the obligation to submit a declaration is a measure of the necessary behavior of the civil servant, its implementation does not depend on his will, and this obligation is ensured by the possibility of use of state coercion. It has been proven that the obligation to file an anticorruption declaration is reflected in the obligation to file a declaration in time by filling out an electronic form on the official website of the National Agency on Corruption Prevention with only reliable information, regardless of the type of declaration.
\end{abstract}

Keywords: prevention of corruption, declaration of persons authorized to perform the functions of the state or local self-government, civil service, duty, electronic form.

Вступ. Дотримання антикорупційного законодавства є критерієм якості та ефективності функціонування державної влади. Незважаючи на це, корупція $є$ системним деформуючим фактором, який в тій чи іншій мірі впливає на стан державно-управлінських відносин у кожній державі. Не виключенням є Україна, де рівень корумпованості публічних службовців достатньо високий. Запровадження засобів фінансового контролю як запорука доброчесності державних службовців спрямовано на появу зобов'язання з подання декларацій осіб, яких уповноважено на виконання функцій держави або місцевого самоврядування. Проблематика визначення якісних та процедурних ознак подання декларацій осіб, яких уповноважено на виконання функцій держави або місцевого самоврядування державними службовцями відображає зміст інституту державної служби та $є$ надзвичайно актуальною з огляду на докорінні зміни, які торкнулись антикорупційного законодавства.

Стан дослідження. Суттєвий науковий внесок у розробку концептуальних засад застосування заходів фінансового контролю до державних службовців було зроблено такими вченими, як: В.Б. Авер'янов, О.Ф. Андрійко, Л.Р. Біла-Тіунова, К.Л. Бугайчук, В.В. Галунько, В.М. Гаращук, О.О. Дудоров, Д.Г. Михайленко, А.В. Титко, М.І. Хавронюк, О.П. Хамходера та ін. У той же час, значна кількість питань, пов'язаних з визначенням специфіки подання декларацій осіб, яких уповноважено на виконання функцій держави або місцевого самоврядування державним службовцем залишається невирішеною з врахуванням нормотворчого реформування способу подання декларації та зміни ії структурних елементів, що свідчить про актуальність обраної теми дослідження.

Мета дослідження полягає у тому, щоб на основі аналізу існуючих наукових підходів та вітчизняного правового забезпечення дотримання вимог антикорупційного фінансового контролю 
державними службовцями дослідити ознаки подання декларацій осіб, яких уповноважено на виконання функцій держави або місцевого самоврядування в якості обов'язку державного службовця.

Виклад основного матеріалу. Спеціальний статус державного службовця, якого пов'язано 3 здійсненням особливого роду діяльності - виконанням функцій держави, опосередковує наявність спеціальних обов'язків, що покладаються на осіб, які займають посаду державної служби. Усталеним у праві $є$ тлумачення поняття «обов'язку» як нормативно визначеної міри необхідної та належної поведінки. Слушною видається позиція Л.Р. Білої-Тіунової, якою обов'язки державного службовця визначено як передбачені Конституцією і чинним законодавством вимоги діяти у певних межах із дотриманням передбачених правил поведінки ${ }^{1}$. Перелік обов'язків державного службовця закріплено ст. 8 Закону України «Про державну службу» ${ }^{2}$. Виходячи із змісту положень цієї норми, обов'язки державного службовця можливо класифікувати в залежності від їх приналежності та нормативного закріплення на два види: основні обов'язки, яких покладено на усіх державних службовців та, яких прямо закріплено Законом «Про державну службу» та посадові обов'язки, яких покладено на окремих державних службовців в залежності від займаної посади та, яких закріплено у положеннях про структурні підрозділи державних органів та посадових інструкціях, затверджених керівниками державної служби в цих органах ${ }^{3}$.

До основних обов'язків державного службовця віднесено зобов'язання додержуватися вимог законодавства у сфері запобігання і протидії корупції, так як його закріплено п. 9 ч. 1 ст. 8 Закону України «Про державну службу» в якості обов’язку, що стосуються кожного державного службовця. Передумовою дотримання вимог антикорупційного законодавства на різних етапах державної служби $\epsilon$ можливість притягнення державного службовця до дисциплінарної відповідальності за невиконання або неналежне виконання державним службовцем своїх посадових обов'язків, до яких віднесено і обов'язок з антикорупційного декларування (Ст. 65$)^{4}$.

Вказане, нормативно закріплене профільним законом, зобов'язання до діяльності державного службовця має відсильний характер та деталізується нормами Закону України «Про запобігання корупції». Загалом, обов'язок додержуватися вимог законодавства у сфері запобігання і протидії корупції є складно-елементним зобов'язанням, яке включає: обов'язок дотримуватись обмежень щодо використання службових повноважень чи свого становища; обов'язок дотримуватись обмежень щодо одержання подарунків; обов'язок запобігати одержанню неправомірної вигоди або подарунка та поводження з ними; обов'язок дотримуватись обмежень щодо сумісництва та суміщення з іншими видами діяльності; обов'язок дотримуватись етичних норм; обов'язок дотримуватись вимог фінансового контролю і тому подібне .

Хоча антикорупційного фінансовий контроль застосовується як до службовців публічного сектору, так і до осіб, які здійснюють неуправлінську діяльність ${ }^{6}$, його спрямовано на забезпечення дотримання вимог фінансового звітування, виявлення порушень умов фінансової дисципліни, а також застосування заходів адміністративного впливу щодо осіб, які порушили вимоги фінансового контролю. ${ }^{7}$

До заходів фінансового контролю Законом України «Про запобігання корупції» першочергово віднесено подання декларацій осіб, уповноважених на виконання функцій держави або місцевого

\footnotetext{
${ }^{1}$ Біла-Тіунова, Л. (2020). Державна служба України. Одеса, $150<\mathrm{http} / / \mathrm{dspace.onua.edu.ua/bitstream/handle/}$ 11\%201300/12488/ДЕРЖСЛУЖБАпосібник.pdf?sequence=3\&isAllowed=y $>$ (2020, вересень, 10).

2 Закон про державну службу, 2015 (Верховна Рада України). Офічійний сайт Верховної Ради Украйни <https://zakon.rada.gov.ua/laws/show/889-19\#Text> (2020, вересень, 10).

${ }^{3}$ Галунько, В., Правоторова, О. (2020). Адміністративне право України. Київ: Академія адміністративноправових наук. 466. < http://sipl.com.ua/wp-content/uploads/2020/03/Адміністративне-право-України.-Повнийкурс-підручник-2020.pdf> (2020, вересень, 10).

4 Закон про державну службу, 2015 (Верховна Рада України). Офічійний сайт Верховної Ради Украӥни $<$ https://zakon.rada.gov.ua/laws/show/889-19\#Tехt> (2020, вересень, 10).

5 Закон про запобігання корупиії, 2014 (Верховна Рада України). Офіційний сайт Верховної Ради Украйни <https://zakon.rada.gov.ua/laws/show /1700-18\#Text> (2020, вересень, 10).

${ }^{6}$ Михайленко Д. (2017). Протидія корупційним злочинам засобами кримінального права: концептуальні основи. Одеса: Гельветика, 112.

${ }^{7}$ Хабарова Т. (2017). Адміністративно-процесуальні засади запобігання корупиії в Україні: дисертація на здобуття наукового ступеню кандидата юридичних наук. Харків: Харківський національний університет імені В.Н. Каразіна.
} 
самоврядування, облік та оприлюднення декларацій, тому що інші заходи фінансового контролю здійснюються виходячи з якісних ознак дотримання обов'язку щодо подання декларації (мається на увазі, подальше встановлення своєчасності подання декларацій, здійснення повної перевірки декларацій тощо).

Подання декларацій осіб, яких уповноважено на виконання функцій держави або місцевого самоврядування державним службовцем об'єктивізується через сукупність дій щодо подання різних видів декларацій для недопущення, відвернення та сприяння виявленню ознак корупції та порушень антикорупційного законодавства.

Таким чином, обов'язок державного службовця щодо подання декларацій осіб, яких уповноважено на виконання функцій держави або місцевого самоврядування $є$ установленим державою зобов'язанням, що офіційно закріплює міру необхідної поведінки щодо подання декларації осіб, яких уповноважено на виконання функцій держави або місцевого самоврядування в межах суспільних відносин, пов'язаних із дотриманням вимог законодавства у сфері запобігання і протидії корупції.

Обов'язок державного службовця щодо подання декларацій осіб, яких уповноважено на виконання функцій держави або місцевого самоврядування характеризується наступними ознаками: 1) є категорією необхідної поведінки державних службовців та не залежить від їх волі; 2) відображає одне із завдань функціонування державної вдади - запобігання корупції; 3) $є$ персоніфікованим елементом правового статусу державного службовця, який не може бути делегованим чи переданим; 4) опосередковує обмеження щодо поведінки державного службовця; 5) у випадку невиконання обов'язку з антикорупційного декларування до державного службовця можуть бути застосовані заходи юридичної відповідальності тощо.

Стуктурно обов'язок державного службовця щодо подання декларації осіб, яких уповноважено на виконання функцій держави або місцевого самоврядування полягає у зобов'язанні своєчасного подання декларації шляхом заповнення електронної форми на офіційному веб-сайті Національного агентства з питань запобігання корупції з зазначенням виключно достовірних відомостей, незалежно від типу декларації. Невиконання будь-якого із вказаних елементів обов'язку подання декларації осіб, яких уповноважено на виконання функцій держави або місцевого самоврядування (наприклад, несвоєчасне подання декларації, зазначення недостовірних відомостей і тому подібне) спричиняє негативні наслідки для державного службовця у вигляді притягнення до адміністративної, кримінальної, дисциплінарної та морально-етичної відповідальності.

Уявляється доцільним звернути увагу на поняття «декларація осіб, яких уповноважено на виконання функцій держави або місцевого самоврядування», якого використано у Законі України «Про запобігання корупції». Воно є синонімом поняття «антикорупційна декларація» та використовується для позначення різного типу декларацій: а) щорічної декларації, яка подається у період з 00 годин 00 хвилин 01 січня до 00 годин 00 хвилин 01 квітня року, наступного за звітним роком. Така декларація охоплює звітний рік (період з 01 січня до 31 грудня включно), що передує року, в якому подається декларація, та містить інформацію станом на 31 грудня звітного року; б) декларації кандидата, що претендує на зайняття посади державної служби, яка подається до призначення або обрання особи на посаду. Така декларація охоплює звітний рік (період 301 січня до 31 грудня включно), що передує року, в якому особа подала заяву на прийняття посади (участь у конкурсі), якщо інше не передбачено законодавством, та містить інформацію станом на 31 грудня звітного року; в) декларації перед звільненням, яка подається відповідно не пізніше двадцяти робочих днів з дня припинення державної служби; г) декларації після припинення державної служби, яка подається до 00 годин 00 хвилин 01 квітня року, наступного за звітним роком, у якому припинено таку діяльність. Така декларація охоплює звітний рік (період з 01 січня до 31 грудня включно), що передує року, в якому подається декларація, та містить інформацію станом на 31 грудня звітного року ${ }^{1}$.

Отже, в залежності від функціонального призначення антикорупційної декларації та періоду, за який вони мають бути подані можливим $є$ виокремлення різних типів декларації, при цьому первинно будь-який тип декларації державного службовця позначено як декларація осіб, яких уповноважено на виконання функцій держави або місцевого самоврядування.

\footnotetext{
${ }^{1}$ Рімення про форму декларації осіб, уповноважених на виконання функиій держави або місцевого самоврядування, 2016 (Національне агентство з питань запобігання корупції). Офіційний сайт Верховної Ради Украӥни <https://zakon.rada.gov.ua/laws/show/z0960-16> (2020, вересень, 10).
} 
Фактичне виконання або невиконання обов’язку державного службовця щодо подання декларації осіб, яких уповноважено на виконання функцій держави або місцевого самоврядування відображається у визначеному документі - декларації. У межах антикорупційного фінансового контролю, декларація осіб, яких уповноважено на виконання функцій держави або місцевого самоврядування є електронним документом встановленої законом форми, якого має бути подано до Національного агентства 3 питань запобігання корупції. Порівняно новий спосіб подання декларації осіб, яких уповноважено на виконання функцій держави або місцевого самоврядування шляхом електронного ії заповнення спрямовано на підвищення рівня довіри до державних службовців, 3 одного боку та слідування міжнародним стандартам у сфері запобігання корупції - 3 іншого ${ }^{1}$.

Електронний спосіб подання декларації осіб, яких уповноважено на виконання функцій держави або місцевого самоврядування у загальному вигляді $є$ безпечніший, ніж паперовий. Крім того, електронна форма має переваги над паперовою у вигляді скорочення кількості співробітників агентства, до компетенції якого належить забезпечення антикорупійного декларування; скорочення витрат на моніторинг за поданням декларацій; більш тривалий термін зберігання тощо.

Більш детально вимоги до форми декларацій осіб, яких уповноважено на виконання функцій держави та місцевого самоврядування визначено у Рішенні Національного агентства з питань запобігання корупції від 2016 р. № 3 «Форма декларації осіб, уповноважених на виконання функцій держави або місцевого самоврядування»² .

Факт подання декларації осіб, яких уповноважено на виконання функцій держави та місцевого самоврядування державним службовцем підтверджується шляхом надсилання повідомлення суб'єкта декларування на адресу його електронної пошти, вказаної під час реєстрації, а також до його персонального електронного кабінету. Після подання декларації до Єдиного державного реєстру декларацій осіб, уповноважених на виконання функцій держави або місцевого самоврядування, система автоматично надає унікальний ідентифікатор документа та накладає на нього електронну печатку, що унеможливлює внесення несанкціонованих змін до поданого документа (забезпечує цілісність документа) механізм перевірки декларації.

Антикорупційним законодавством до заходів, яких спрямовано на перевірку декларацій осіб, уповноважених на виконання функцій держави або місцевого самоврядування, віднесено такі, як: проведення контролю щодо своєчасності подання декларацій, проведення контролю щодо правильності та повноти заповнення декларацій, застосування логічного та арифметичного контролю та проведення повної перевірки декларацій ${ }^{3}$. Порядок застосування заходів перевірки врегульовано рішенням Національного агентства з питань запобігання корупції від 2017 р. № 56 «Порядок проведення контролю та повної перевірки декларації особи, уповноваженої на виконання функцій держави або місцевого самоврядування» ${ }^{4}$.

Висновки. Підсумовуючи вищезазначене, обов'язок державного службовця щодо подання декларацій осіб, яких уповноважено на виконання функцій держави або місцевого самоврядування можна визначити як установлене державою зобов'язання, що офіційно закріплює міру необхідної поведінки щодо подання декларації осіб, яких уповноважено на виконання функцій держави або місцевого самоврядування в межах суспільних відносин, пов'язаних із дотриманням вимог законодавства у сфері запобігання і протидії корупції. Встановлено, що подання декларацій осіб, яких уповноважено на виконання функцій держави або місцевого самоврядування державним службовцем має вияв у сукупності дій щодо подання різних типів декларацій для недопущення, відвернення та сприяння виявленню ознак корупції та порушень антикорупційного законодавства в Україні. Важливість та широке коло суспільних відносин, в межах яких на державних службовців покладено зобов'язання діяти відповідним чином та розвиток елементів антикорупційного механізму опосередковують потребу здійснення подальших досліджень цієї проблематики.

\footnotetext{
${ }^{1}$ Рябченко, Т., Стеблянко, А. (2017). Електронне декларування як ефективний засіб запобігання корупції в органах місцевого самоврядування. Правові горизонти, 5, 14-19.

2 Рімення про форму декларації осіб, уповноважених на виконання функцій держави або місцевого самоврядування, 2016 (Національне агентство з питань запобігання корупції). Офіиійний сайт Верховної Ради України <https://zakon.rada.gov.ua/laws/show/z0960-16> (2020, вересень, 10).

3 Закон про запобігання корупиії, 2014.(Верховна Рада України). Офіційний сайт Верховної Ради Украйни $<$ https://zakon.rada.gov.ua/laws/show /1700-18\#Tехt> (2020, вересень, 10).

${ }^{4}$ Рішення про порядок проведення контролю та повної перевірки декларації особи, уповноваженої на виконання функцій держави або місиевого самоврядування, 2017 (Національне агентство $з$ питань запобігання корупції). Офіиійний сайт Верховної Ради Украӥни <https://zakon.rada.gov.ua/laws/show/z0362-20\#Техt>. (2020, вересень, 10).
} 


\section{References:}

1. Bila-Tiunova, L. (2020). Derzhavna sluzhba Ukrainy [State service of Ukraine]. Odesa. 511. <http://dspace.onua.edu.ua/bitstream/handle/1 1\%201300/12488/ДЕРЖСЛУЖБАпосібник.pdf?sequence= $3 \&$ isAllowed $=y>$. (2020, September, 10). [in Ukrainian].

2. Halunko, V., Pravotorova, O. (2020). Administratyvne pravo Ukrainy [Administrative law of Ukraine]. Kyiv: Akademiia administratyvno-pravovykh nauk. 466. <http://sipl.com.ua/wp-content/uploads/2020/03/ Адміністративне-право-України.-Повний-курс-підручник-2020.pdf>. (2020, September, 10). [in Ukrainian].

3. Zakon pro derzhavnu sluzhbu, 2015 (Verkhovna Rada Ukrainy) [Law on state Service, 2015, (Verkhovna Rada of Ukraine)]. Ofitsiinyi sait Verkhovnoi Rady Ukrainy [Official site of the Verkhovna Rada of Ukraine] <https://zakon.rada.gov.ua/laws/show/889-19\#Text>. (2020, September, 10). [in Ukrainian].

4. Mykhailenko, D. (2017). Protydiia koruptsiinym zlochynam zasobamy kryminalnoho prava: kontseptualni osnovy: monohrafiia [Counteraction to corruption crimes by means of criminal law: conceptual bases: monograph]. Odesa: Helvetica Publishing House. [in Ukrainian].

5. Rishennia pro poriadok provedennia kontroliu ta povnoi perevirky deklaratsii osoby, upovnovazhenoi na vykonannia funktsii derzhavy abo mistsevoho samovriaduvannia, 2017 (Natsionalne ahentstvo z pytan zapobihannia koruptsii) [Decision on the procedure for control and full verification of the declaration of a person authorized to perform the functions of the state or local self-government, 2017 (National Agency for the Prevention of Corruption)]. Ofitsiinyi sait Verkhovnoi Rady Ukrainy [Official site of the Verkhovna Rada of Ukraine] <https://zakon.rada.gov.ua/laws/show/z0362-20\#Text>. (2020, September, 10). [in Ukrainian].

6. Rishennia pro formu deklaratsii osib, upovnovazhenykh na vykonannia funktsii derzhavy abo mistsevoho samovriaduvannia, 2016 (Natsionalne ahentstvo z pytan zapobihannia koruptsii) [Decision on the form of declaration of persons authorized to perform the functions of state or local self-government, 2016 (National Agency for Prevention of Corruption)]. Ofitsiinyi sait Verkhovnoi Rady Ukrainy [Official site of the Verkhovna Rada of Ukraine]. <https://zakon.rada.gov. ua/laws/show/z0960-16>. (2020, September, 10). [in Ukrainian].

7. Riabchenko, T., Steblianko, A. (2017). Elektronne deklaruvannia yak efektyvnyi zasib zapobihannia koruptsii $\mathrm{v}$ orhanakh mistsevoho samovriaduvannia [Electronic declaration as an effective means of preventing corruption in local governments.]. Pravovi horyzonty [Legal Horizons], 5, 14-19. [in Ukrainian].

8. Zakon pro zapobihannia koruptsii, 2014 (Verkhovna Rada Ukrainy) [Law on Prevention of Corruption: 2014. (Verkhovna Rada of Ukraine)]. Ofitsiinyi sait Verkhovnoi Rady Ukrainy [Official site of the Verkhovna Rada of Ukraine]. <https://zakon.rada.gov.ua/laws/show/1700-18\#Text>. (2020, September, 10). [in Ukrainian].

9. Khabarova, T. (2017). Administratyvno-protsesualni zasady zapobihannia koruptsii v Ukraini [Administrative and procedural principles of corruption prevention in Ukraine]. Kharkiv: VN Karazin Kharkiv National University [in Ukrainian]. 